\title{
PENGARUH MACAM DAN WAKTU PEMBERIAN AIR KELAPA (Cocos nucifera L.) TERHADAP PERTUMBUHAN DAN PRODUKSI TANAMAN PADI (Oryza sativa L.) VARIETAS CIHERANG
}

\section{INFLUENCE OF KINDS AND TIME FOR ADDITION OF COCONUT WATER (Cocos nucifera L.) ON GROWTH AND RICE PLANT (Oryza sativa L.) CIHERANG VARIETY PRODUCTION}

\author{
Aida Naswa Aulia ${ }^{1)}$, Elik Murni Ningtias Ningsih' ${ }^{1)}$ dan Untung Sugiarti ${ }^{1)}$ \\ 1) Fakultas Pertanian, Universitas Widyagama Malang \\ Email : naswaaidaaulia@gmail.com
}

\begin{abstract}
ABSTRAK
Tujuan penelitian ini adalah untuk mengetahui pengaruh macam dan waktu pemberian air kelapa terhadap pertumbuhan padi (Oryza sativa L.). Hasil penelitian menunjukkan terjadi interaksi waktu pemberian dan macam air kelapa terhadap parameter jumlah anakan umur 56 hst dan jumlah anakan produktif umur $97 \mathrm{hst}$, tetapi tidak terjadi pada parameter panjang tanaman, malai terpanjang, jumlah biji per malai, berat seratus butir, berat kering panen, dan berat kering per rumpun. Perlakuan waktu pemberian air kelapa memberikan respon terbaik terhadap panjang tanaman 14 dan 28 hst. Perlakuan macam air kelapa memberikan respon terbaik terhadap panjang tanaman $42 \mathrm{hst}$.
\end{abstract}

Kata kunci : macam air kelapa, waktu pemberian, air kelapa, tanaman padi

\begin{abstract}
This aim of the research was to know the effect of the kind and time application of coconut water on the growth of rice (Oryza sativa L.). The result of the research shows that there is interaction between time application and kinds of coconut water to the parameters of the total of shoots at 56 day after planting (dap) and the productive shoots at 97 day after planting. However, it does not occur in the parameters of the length of the plant, the longest panicle, the total of seeds each panicle, the weight of one hundred grains, the dry weight of the harvest, and the dry weight of grain each clump. Treatment time of coconut water gives best response to length of plant at 14 and 28 day after planting. Coconut water treatment gives the best response to length of plant at 42 day after planting
\end{abstract}

Keywords : kinds of coconut water, time application, coconut water, rice plant

\section{PENDAHULUAN}

Padi (Oriza sativa L.) merupakan komoditas penting dan menempati urutan pertama di Indonesia. Air kelapa merupakan salah satu produk tanaman yang dapat dimanfaatkan untuk meningkatkan pertumbuhan tanaman. Air kelapa diduga me- 
ngandung hormon pertumbuhan, yakni sitokinin dan auksin. Dalam suatu penelitian, kandungan sitokinin dalam air kelapa ialah sebesar 5,8 $\mathrm{mg} / \mathrm{l}$, sedangkan auksin sesebsar 0,07 mg/l (Yusnida dalam Sutono, 2015), kalium, dan mineral, di antaranya Kalsium (Ca), Natrium $(\mathrm{Na})$, Magnesium (Mg), Ferum (Fe), Cuprum (Cu), dan Sulfur (S), gula dan protein. (Suryanto, 2009 dalam Tiwery, 2014).

Pemberian air kelapa dapat meningkatkan pertumbuhan tanaman. Hasil penelitian Darlina, dkk (2016) menyatakan bahwa penyiraman air kelapa memberikan pengaruh nyata terhadap pertumbuhan vegetatif tanaman lada (Piper ningrum L.). Hasil penelitian Katuuk dalam Tiwery (2014) juga menyatakan bahwa pemberian $250 \mathrm{ml} / \mathrm{l}$ air kelapa menunjukkan waktu yang paling tepat dalam perkecambahan biji anggrek macan (Grammatohyllum sciptum). Sedangkan menurut Ramda dalam Hayati (2011), produk hormon dari air kelapa ini mampu meningkatkan hasil kedelai hingga 64\%, kacang tanah hingga $15 \%$ dan sayuran hingga 20 $30 \%$.
Penelitian ini bertujuan untuk mengetahui pengaruh macam dan waktu pemberian air kelapa (Cocos nucifera L.) dan terhadap pertumbuhan dan produksi tanaman padi (Oryza sativa L.) Varietas Ciherang.

\section{METODE PENELITIAN}

Penelitian ini dilaksanakan di Rumah Kaca Kampus III Fakultas Pertanian Universitas Widyagama Malang, Kelurahan Mojolangu, Kecamatan Lowokwaru, Kota Malang. Tempat penelitian ini berada pada ketinggian 470 meter di atas permukaan laut, suhu rata-rata $24^{\circ} \mathrm{C}-$ $25^{\circ} \mathrm{C}$, curah hujan 2000-3000 mm/tahun. Penelitian dirancang dengan menggunakan metode Rancangan Acak Lengkap (RAL) yang disusun secara faktorial, terdiri dari dua faktor yang diulang sebanyak 3 kali. Faktor pertama adalah waktu pemberian air kelapa (A) yang terdiri dari 4 taraf yaitu: $\mathrm{A} 1=$ diberikan selama 3 jam sebelum semai dengan cara merendam benih, $\mathrm{A} 2=$ diberikan saat tanaman memasuki fase generatif, A3 = diberikan saat tanaman memasuki fase generatif dan pengisian 
biji, dan $\mathrm{A} 4=$ diberikan setiap dua minggu sekali.

Faktor kedua adalah macam air kelapa (F) yang terdiri 3 taraf yaitu: $\mathrm{F} 0=$ air kelapa tanpa fermentasi, F1 = air kelapa terfermentasi 7 hari, dan F2 = air kelapa terfermentasi 14 hari. Pengapli kasian air kelapa dilakukan dengan dosis $200 \mathrm{ml} /$ tanaman.

Pengamatan non destruktif mulai umur 14 hst sampai 70 hst dengan interval 14 hari meliputi parameter panjang tanaman, dan jumlah anakan total. Sedangkan jumlah anakan produktif diamati umur 84 dan 97 hst. Ada pun pengamatan destruktif dilakukan saat panen meliputi parameter malai terpanjang, jumlah biji per malai berat seratur butir, berat kering panen, dan berat kering gabah per rumpun.

Data hasil penelitian dianalisa dengan analisa ragam pada taraf $\alpha=5 \%$. Untuk menguji pengaruh perbedaan di antara perlakuan dilakukan dengan Uji Tukey pada $\operatorname{taraf} \alpha=5 \%$.

\section{HASIL DAN PEMBAHASAN}

\section{Panjang tanaman}

Hasil penelitian menunjukkan bahwa waktu pemberian air kelapa berpengaruh sangat nyata terhadap panjang tanaman padi pada 14 dan 28 hst. Sedangkan macam air kelapa berpengaruh nyata terhadap panjang tanaman pada 56 hst, seperti pada Tabel 1.

Tabel 1. Rerata Pengaruh Waktu Pemberian dan Macam Air Kelapa terhadap Panjang Tanaman

\begin{tabular}{cccccc}
\hline \multirow{2}{*}{ Perlakuan } & \multicolumn{5}{c}{ Umur pengamatan $(\mathrm{cm})$} \\
& $14 \mathrm{hst}$ & $28 \mathrm{hst}$ & $42 \mathrm{hst}$ & $56 \mathrm{hst}$ & $70 \mathrm{hst}$ \\
\hline A1 & $29,96 \mathrm{~b}$ & $41,96 \mathrm{~b}$ & 58,15 & 71,70 & 79,87 \\
A2 & $22,01 \mathrm{a}$ & $37,76 \mathrm{a}$ & 54,36 & 65,91 & 78,72 \\
A3 & $23,00 \mathrm{a}$ & $38,46 \mathrm{ab}$ & 54,67 & 69,30 & 80,95 \\
A4 & $22,59 \mathrm{a}$ & $36,78 \mathrm{a}$ & 54,14 & 69,38 & 79,57 \\
\hline Tukey 5\% & 9,00 & 9,00 & tn & tn & tn \\
\hline F0 & 24,58 & 38,51 & 56,27 & $72,50 \mathrm{~b}$ & 80,90 \\
F1 & 24,19 & 38,37 & 53,75 & $65,72 \mathrm{a}$ & 78,69 \\
F2 & 24,40 & 39,33 & 56,57 & $69,00 \mathrm{ab}$ & 79,75 \\
\hline Tukey 5\% & tn & tn & tn & 12,00 & tn \\
\hline
\end{tabular}

Keterangan : Angka - angka yang diikuti dengan huruf yang sama pada satu kolom menunjukkan tidak berbeda nyata berdasakan uji Tukey $5 \%, \mathrm{tn}=$ tidak berpengaruh nyata. 
Perlakuan A1 menghasilkan panjang tanaman yang lebih tinggi dibanding dengan perlakuan A2, A3, dan A4. Hal ini diduga karena perlakuan A1 kandungan hormon auksin dalam air kelapa berperan penting bagi perkecambahan benih. Hormon auksin dapat mematahkan dormansi benih dan akan merangsang proses perkecambahan benih, dapat memacu sitokinesis yang menyebabkan terjadinya peningkatan jumlah sel, dan giberelin berfungsi dalam mobilisasi bahan makanan selama fase perkecambahan (Abidin, 1982).

Macam air kelapa (F0) memberikan hasil terbaik dibandingkan perlakuan F1 dan F2. Hal ini diduga karena dalam F0, kandungan hormon pertumbuhan dan mineral penting dalam air kelapa masih dalam keadaan utuh. Nitrogen (N) dalam air kelapa berperan dalam penyusun protoplasma secara keseluruan sebab $\mathrm{N}$ merupakan salah satu unsur hara yang sangat penting bagi tanaman (Arinong, 2014), fosfor (P) dalam air kelapa berperan penting dalam pembentukan asam nukleat, perkembangan akar, pertumbuhan awal tanaman, luas daun, hingga mempercepat panen (Adam, 2003), Kalium (K) berperan penting dalam proses metabolisme tanaman (Sarief dalam Arinong, 2014).

\section{Jumlah Anakan}

Perlakuan interaksi macam air kelapa dan waktu pemberian air kelapa berpengaruh nyata terhadap jumlah anakan pada 42 hst (Tabel 2). Sedangkan perlakuan waktu pemberian air kelapa dan macam air kelapa tidak berpengaruh nyata terhadap jumlah anakan pada 14 sampai 70 hst (Tabel 3).

Kombinasi perlakuan A3F2 menghasilkan jumlah anakan paling banyak dibandingkan dengan kombinasi perlakuan lainnya. Hal ini diduga karena waktu pemberian, kandungan serta mekanisme penyerapan hormon pertumbuhan dalam air kelapa terfermentasi. Hormon pertumbuhan dalam jumlah tertentu dapat mempengaruhi pertumbuhan. Kandungan nitrogen dalam air kelapa terfermentasi 14 hari (F2) dapat membantu pertumbuhan tanaman. Sedangkan $\mathrm{pH}$ asam yang akibat fermentasi F2 memungkinkan dalam pengambilan auksin. Pengambilan auksin meningkat seiring dengan menurunnya $\mathrm{pH}$ media. Semakin rendahnya $\mathrm{pH}$, maka semakin besar pula gradien $\mathrm{pH}$ melintas 
plasmalemma yang selanjutnya akan meningkatkan masuknya auksin ke dalam sel (Edwards dan Goldsmith, 1980 dalam Anonim, 1993)

Tabel 2. Rerata Pengaruh Kombinasi Perlakuan Waktu Pemberian dan Macam Air Kelapa terhadap Jumlah Anakan Per Rumpun Padi Umur Pengamatan 42 HST

\begin{tabular}{cc}
\hline Kombinasi Perlakuan & Rerata pengamatan \\
\hline A1F0 & $29,16 \mathrm{ab}$ \\
A1F1 & $27,50 \mathrm{ab}$ \\
A1F2 & $23,83 \mathrm{ab}$ \\
A2F0 & $29,16 \mathrm{ab}$ \\
A2F1 & $26,50 \mathrm{ab}$ \\
A2F2 & $21,83 \mathrm{ab}$ \\
A3F0 & $26,50 \mathrm{ab}$ \\
A3F1 & $20,66 \mathrm{ab}$ \\
A3F2 & $33,16 \mathrm{~b}$ \\
A4F0 & $28,16 \mathrm{ab}$ \\
A4F1 & $25,66 \mathrm{ab}$ \\
A4F2 & $19,33 \mathrm{a}$ \\
\hline Tukey 5\% & 3,00 \\
\hline
\end{tabular}

Keterangan : Angka - angka yang diikuti dengan huruf yang sama pada satu kolom menunjukkan tidak berbeda nyata berdasakan uji Tukey $5 \%, \mathrm{tn}=$ tidak berpengaruh nyata.

Keasaman $(\mathrm{pH})$ media berpengaruh terhadap pengambilan garamgaram oleh sel-sel atau jaringan tanaman. Pada kultur suspense Jponema $s p$, laju pengunaan $\mathrm{NO}_{3}{ }^{-}$meningkat seiring dengan menurunnya $\mathrm{pH}$ media, sedangkan $\mathrm{NH}_{4}{ }^{+}$meningkat seiring dengan meningkatnya $\mathrm{pH}$ media (Rose dan Martin, 1975 dalam Anonim, 1993). Nitrogen umumnya diserap tanaman dalam bentuk $\mathrm{NH}_{4}{ }^{+}$atau $\mathrm{NO}_{3}{ }^{-}$ tergantung jenis tanaman dan tahap pertumbuhannya.

Tabel 3 menunjukkan bahwa perlakuan waktu pemberian dan macam air kelapa tidak berpengaruh nyata terhadap jumlah anakan pada 14 sampai 70 hst. Hal ini diduga karena absorbsi hormon tumbuh di dalam sel sudah dalam keadaan seimbang sehingga penambahan hormon tumbuh tidak dapat meningkatkan jumlah hormon dalam tanaman. Hal ini sesuai dengan pernyataan Campbell, et al (2002) dalam Pamungkas, dkk (2009), bahwa sel tumbuhan akan mengalami pembengkakan jika air atau cairan masuk secara osmosis, namun jika konsentrasi cairan di sekitar sel tumbuhan isotonis maka air tidak akan masuk kembali ke dalam sel. 
Tabel 3. Rerata Pengaruh Waktu Pemberian dan Macam Air Kelapa terhadap Jumlah Anakan Tanaman Padi

\begin{tabular}{cccccc}
\hline \multirow{2}{*}{ Perlakuan } & \multicolumn{5}{c}{ Umur pengamatan (tanaman) } \\
& $14 \mathrm{hst}$ & $28 \mathrm{hst}$ & $42 \mathrm{hst}$ & $56 \mathrm{hst}$ & $70 \mathrm{hst}$ \\
\hline A1 & 4,83 & 19,33 & 26,83 & 22,16 & 22,16 \\
A2 & 5,05 & 17,44 & 25,83 & 20,78 & 20,78 \\
A3 & 4,22 & 17,61 & 26,77 & 24,11 & 24,11 \\
A4 & 3,83 & 14,55 & 24,38 & 22,61 & 22,61 \\
\hline Tukey 5\% & tn & tn & tn & tn & tn \\
\hline F0 & 4,66 & 16,79 & 26,91 & 22,96 & 22,96 \\
F1 & 4,20 & 18,37 & 25,08 & 22,16 & 22,16 \\
F2 & 4,58 & 16,54 & 25,87 & 22,12 & 22,12 \\
\hline Tukey 5\% & tn & tn & tn & tn & tn
\end{tabular}

Keterangan : Angka - angka yang diikuti dengan huruf yang sama pada satu kolom menunjukkan tidak berbeda nyata berdasakan uji Tukey $5 \%, \mathrm{tn}=$ tidak berpengaruh nyata.

\section{Jumlah Anakan Produktif}

Hasil penelitian menunjukkan bahwa tidak terdapat perbedaan nyata kombinasi macam air kelapa dan waktu pemberian air jumlah anakan produktif umur 97 hst. Demikian halnya dengan perlakuan tunggal waktu pemberian air kelapa dan macam air kelapa, tidak berpengaruh nyata terhadap jumlah anakan produktif umur 84 dan 97 hst (Tabel $5)$.

Tabel 5. Rerata Pengaruh Waktu Pemberian dan Macam Air Kelapa terhadap Jumlah Anakan Produktif Rumpun Padi

\begin{tabular}{ccc}
\hline \multirow{2}{*}{ Perlakuan } & \multicolumn{2}{c}{ Umur pengamatan (tanaman) } \\
& $84 \mathrm{hst}$ & $97 \mathrm{hst}$ \\
\hline A1 & 15,55 & 16,22 \\
A2 & 12,11 & 16,00 \\
A3 & 12,00 & 16,44 \\
A4 & 13,00 & 16,11 \\
\hline Tukey 5\% & tn & tn \\
\hline F0 & 13,54 & 16,29 \\
F1 & 12,08 & 15,83 \\
F2 & 13,87 & 16,45 \\
\hline
\end{tabular}
Tukey 5\%

tn
tn

Keterangan : Angka - angka yang diikuti dengan huruf yang sama pada satu kolom menunjukkan tidak berbeda nyata berdasakan uji Tukey $5 \%, \mathrm{tn}=$ tidak berpengaruh nyata .

Hal ini diduga karena faktor lain di luar kontrol yang mempengaruhi pertumbuhan tanaman. Menurut
Ramadan, dkk (2016), proses metabolisme dalam tanaman dipengaruhi beberapa faktor, baik faktor dari dalam 
tanaman semisal kondisi bahan tanam dan kandungan senyawa dalam tanaman, sedangkan faktor dari luar tanaman meliputi zat pengatur tumbuh serta kondisi lingkungan semisal suhu, intensitas cahaya, ataupun kelembaban.

\section{Malai Terpanjang dan Jumlah Biji/} Malai

Hasil penelitian menunjukkan tidak ada interaksi dan pengaruh nyata waktu pemberian dan macam air kelapa terhadap jumlah malai terpanjang mau pun jumlah biji/malai (Tabel 6).

Tabel 6. Rerata Pengaruh Waktu Pemberian dan Macam Air Kelapa terhadap Malai Terpanjang dan Jumlah Biji Per Malai

\begin{tabular}{ccc}
\hline \multirow{2}{*}{ Perlakuan } & \multicolumn{2}{c}{ Pengamatan } \\
\cline { 2 - 3 } & $\begin{array}{c}\text { MTP } \\
(\mathrm{cm})\end{array}$ & $\begin{array}{c}\text { JBPM } \\
(\text { butir })\end{array}$ \\
\hline A1 & 21,61 & 118,94 \\
A2 & 21,76 & 91,94 \\
A3 & 21,69 & 106,05 \\
A4 & 21,63 & 94,56 \\
\hline Tukey 5\% & tn & tn \\
\hline F0 & 21,77 & 98,00 \\
F1 & 21,51 & 102,62 \\
F2 & 21,77 & tn
\end{tabular}

Keterangan : Angka - angka yang diikuti dengan huruf yang sama pada satu kolom menunjukkan tidak berbeda nyata berdasakan uji Tukey $5 \%, \mathrm{tn}=$ tidak berpengaruh nyata .

Hal ini diduga karena pengaruh faktor lain di luar kontrol, salah satunya ialah angin. Angin memiliki peran yang penting terhadap pertumbuhan dan perkembangan tanaman padi. Dengan angin, tanaman padi dapat melakukan penyerbukan dan pembuahan (Ina, 2007 dalam Mubaroq, 2013). Angin kencang yang panas merusak proses pembungaan. Kegagalan dalam proses pembungaan dan penyerbukan akan berpengaruh terhadap pembentukan biji (Elisa, 2017).

\section{Berat Seratus Butir, Berat Kering Panen, dan Berat Kering Gabah/ Rumpun}

Hasil penelitian menunjukkan tidak ada interaksi dan pengaruh nyata waktu pemberian dan macam air kelapa terhadap terhadap berat 100 butir, berat kering panen, dan berat kering gabah/rumpun padi (Tabel 7). 
Tabel 7. Rerata Pengaruh Waktu Pemberian dan Macam Air Kelapa terhadap Berat Seratus Butir, Berat Kering Panen, dan Berat Kering Gabah/Rumpun

\begin{tabular}{cccc}
\hline \multirow{2}{*}{ Perlakuan } & \multicolumn{3}{c}{ Pengamatan } \\
\cline { 2 - 4 } & $\begin{array}{c}\text { BSB } \\
\text { (gram) }\end{array}$ & $\begin{array}{c}\text { BKP } \\
\text { (gram) }\end{array}$ & $\begin{array}{c}\text { BKG } \\
\text { (gram) }\end{array}$ \\
\hline A1 & 2,57 & 25,89 & 24,24 \\
A2 & 2,16 & 21,39 & 17,36 \\
A3 & 2,30 & 20,05 & 19,32 \\
A4 & 2,31 & 21,99 & 20,06 \\
\hline Tukey 5\% & tn & tn & tn \\
\hline F0 & 2,38 & 24,99 & 16,73 \\
F1 & 2,29 & 17,93 & 20,61 \\
F2 & 2,33 & 24,08 & tn \\
\hline Tukey 5\% & tn & tn
\end{tabular}

Keterangan : Angka - angka yang diikuti dengan huruf yang sama pada satu kolom menunjukkan tidak berbeda nyata berdasakan uji Tukey $5 \%, \mathrm{tn}=$ tidak berpengaruh nyata.

Hal ini diduga karena adanya pengaruh faktor lain yang di luar kontrol, salah satunya ialah sinar matahari. Sinar matahari berperan penting dalam proses fisiologi tanaman, terutama fotosintesis, respirasi, dan transpirasi. Intensitas sinar matahari sangat mempengaruhi proses pembungaan dan pemasakan buah pada tanaman padi. Penelitian yang dilaksanakan di rumah kaca (greenhouse) Fakultas Pertanian Universitas Widyagama ini diduga mengakibatkan intensitas dan jumlah sinar matahari yang diterima tanaman menjadi berkurang. Hal ini karena, saat di lapang tanaman dalam kondisi tidak ternaungi sehingga radiasi sinar matahari dapat langsung sampai ke tanaman. Sedangkan saat di dalam rumah kaca (greenhouse) tanaman dalam kondisi ter- naungi sehingga radiasi sinar matahari harus diteruskan terlebih dahulu atau bahkan terhalang untuk sampai ke tanaman.

Menurut Sopandie, dkk (2003) dalam Pantilu dkk (2010), naungan $50 \%$ pada genotipe padi dapat menyebabkan jumlah gabah / malai kecil serta persentase gabah hampa yang tinggi, sehingga produksi biji rendah. Intensitas sinar matahari rendah pada saat pembungaan padi dapat menurunkan karbohidrat yang terbentuk, sehingga menyebabkan meningkatnya gabah hampa.

Selain sinar matahari, cara pengaplikasian air kelapa diduga dapat mempengaruhi hasil produksi. Air kelapa diberikan dengan cara disiram ke tanaman. menyebabkan kandungan hara tidak dapat diserap secara 
langsung oleh jaringan tanaman dibandingkan dengan cara disemprot. Penyemprotan bertujuan untuk mempercepat penyerapan hara, yakni melalui daun. Pada tanaman padi, permukaan daun terasa kasar dan berambut. Hal ini diduga dapat menyebabkan hara yang disemprotkan pada daun tidak dapat diserap secara maksimal, sehingga dapat mempengaruhi pertumbuhan dan produksi tanaman.

\section{KESIMPULAN DAN SARAN}

\section{Kesimpulan}

Berdasarkan penelitian yang dilakukan dapat disimpulkan bahwa:

1. Waktu pemberian air kelapa pada taraf A1 memberikan hasil terbaik terhadap panjang tanaman pada 14 dan 28 hst.

2. Macam air kelapa pada taraf F0 memberikan respon terbaik terhadap panjang tanaman pada 42 hst.

3. Kombinasi perlakuan A3F2 memberikan hasil terbaik terhadap jumlah anakan/ rumpun pada $42 \mathrm{hst}$.

4. Waktu pemberian, macam air kelapa, dan kombinasi waktu pemberian dan macam air kelapa tidak memberikan pengaruh nyata terhadap malai terpanjang, jumlah biji per malai, berat seratus butir, berat kering panen dan berat kering gabah per rumpun padi.

\section{Saran}

Saran penelitian ini adalah:

1. Perlu adanya penelitian lanjut agar interaksi kedua perlakuan memberikan hasil yang nyata terhadap semua parameter pengamatan dengan memperhatikan cara pengaplikasian air kelapa sesuai stadia pertumbuhan tanaman padi.

2. Perlu adanya penelitian lebih lanjut mengenai konsentrasi dan dosis aplikasi macam air kelapa agar didapatkan hasil yang nyata terhadap semua parameter pengamatan.

\section{DAFTAR PUSTAKA}

Abidin, Z. 1982. Dasar-dasar Pengetahuan tentang Zat Pengatur Tumbuh. Penerbit Angkasa. Bandung.

Adam, S. Yuliyanti, M. I. Bahua, dan F. S. Jamin. 2013. Pengaruh Pupuk Fosfor pada Pertumbuhan dan Produksi Tanaman Mentimun (Cucumis sativus L.).

Arinong, R. 2014. Peranan Unsur Hara dalam Tanaman http://www.stppgowa.ac.id/infor masi/artikel-ilmiah/250-peranan- 
unsur-hara-dalam-tanaman.htm

Diakses pada 06 Maret 2016 Pukul 07:30 WIB.

Campbell, N.A., J.B. Reece, and L.G. Mithcell 2002. Biologi. Alih Bahasa: Wasmen Manalu. Erlangga. Jakarta.

Darlina, H. dan H. Rahmatan. 2016. Pengaruh Penyiraman Air Kelapa (Cocos nucifera) terhadap Pertumbuhan Vegetatif Lada (Piper ningrum L.). Jurnal Ilmiah Mahasiswa Pendidikan Biologi. 1(1): 25-27.

Elisa. 2017. Faktor-faktor yang Mem pengaruhi Pertumbuhan Tanaman. Universitas Gajahmada diakses dalam http://repository.ugm.ac.id Tanggal 18 Oktober 2017 Pukul 16.03 WIB.

Ina, H. 2007. Bercocok Tanam Padi. Azka Mulia Media. Jakarta.

Mubaroq, I. A. 2013. Kajian Potensi Bionutrien Caf dengan Penambahan Ion Logam terhadap Pertumbuhan dan Perkembangan Tanaman Padi. Universitas Pendidikan Indonesia. Diakses dalam http://www.repository.upi.edu Tanggal 18 Oktober 2017 Pukul 14.00 WIB.

Pamungkas, F. T., D. Sri., dan R. Budi. 2009. Pengaruh Konsentrasi dan Lama Perendaman dalam Supernatan Kultur Bacillus sp. 2 Ducc BRK1.3 Terhadap Pertumbuhan Stek Horizontal Batang Jarak Pagar (Jatropha curcas L.). Jurnal Sains dan Matematika.
17(3). Universitas Diponegoro. Semarang.

Pantilu, L. I., Mantiri Feley R, S. Ai Nio, dan P. Dingse. 2012. Respon Morfologi dan Anatomi Kecambah Kacang Kedelai (Glycine max L. Merill) terhadap Intensitas Cahaya yang Berbeda. Jurnal Bioslogis. 2(2): 80-83.

Ramda, A. dalam Ajizah. 2011. Pengaruh Frekuensi dan Pemberi an Air Kelapa Terhadap Pertum buhan dan Hasil Jamur Merang (Volvariella volvaceae). Skripsi. Universitas Jember. Jember.

Sopandie, D., M.A. Chozin, S. Sastrosumarjo, T. Juhaeti dan Sahardi. 2003. Toleransi Padi Gogo Terhadap Naungan. Jurnal Hayati. 10: 71-72.

Suryanto, E. 2009. Air Kelapa dalam Media Kultur Anggrek dalam R.R. Tiwery. 2014. Pengaruh Penggu naan Air Kelapa (Cocos nucifera) untuk Pertumbuhan Tanaman Sawi (Brassica juncea L.). Sekolah Pertanian Pembangunan Provinsi Maluku. Jurnal Biopendix. 1(1): 84-89. 